\title{
Phytochemical investigation and antimicrobial appraisal of Parrotiopsis jacquemontiana (Decne) Rehder
}

\author{
Saima Ali, Muhammad Rashid Khan*, Irfanullah, Moniba Sajid and Zartash Zahra
}

\begin{abstract}
Background: Parrotiopsis jacquemontiana (Decne) Rehder. is locally used for skin infections and in wound healing. In this study we have evaluated methanol extract of its leaves and derived fractions against the clinical multi-drug resistant bacterial strains.

Methods: P. jacquemontiana leaves powder extracted with 95\% methanol (PJM) and fractionated in escalating polarity of solvents; n-hexane (PJH), chloroform (PJC), ethyl acetate (PJE), n-butanol (PJB) and the remaining as aqueous fraction (PJA). Clinical as well as environmental 19 bacterial strains and 8 fungal strains were screened for minimum inhibitory concentration (MIC) and minimum bactericidal/fungicidal concentration (MBC/MFC). Preliminary phytochemical investigation for various phytochemical classes was also carried out.

Results: PJM contained the coumarins, phenols, flavonoids, tannins, alkaloids, glycosides, saponins, sterols, phlobatannins, steroids, phytosterols, triterpenoids, acids, quinones, proteins, vitamin C, betacyanins, oils and resins while anthraquinones, phytosteroids, carbohydrates and anthocyanins were not detected. Disc diffusion assay (1 mg/disc) indicated the sensitivity of all the MDR strains of bacteria with PJM, PJE and PJB, while no inhibition was recorded with PJA. PJH and PJC inhibited the growth of all the strains of Staphylococcus aureus, Pseudomonas aeruginosa and Coagulase negative staphylococci used in this study. Maximum zone of inhibition $(35.5 \pm 1.32 \mathrm{~mm})$ was obtained with PJM against Staphylococcus lugdenesis MDR (6197). Comparatively lower MIC $(8-64 \mu \mathrm{g} / \mathrm{ml})$ and MBC $(32-256 \mu \mathrm{g} / \mathrm{ml})$ values were recorded for PJM and PJE. In case of fungal strains only PJM, PJE and PJB markedly inhibited the growth and lower MIC (8-128 $\mu \mathrm{g} / \mathrm{ml})$ and MFC (32-512 $\mu \mathrm{g} / \mathrm{ml})$ values were determined for PJM and PJE.
\end{abstract}

Conclusion: The remarkable inhibition of various bacterial and fungal strains at low doses of the extract/fractions suggested the strong antibacterial, antifungal and anti-candidal potential of $P$. jacquemontiana leaves.

Keywords: Parrotiopsis jacquemontiana, Multi drug resistance, Minimum inhibitory concentration, Bacterial strains, Fungal strains

\section{Background}

Infectious diseases represent one of the major health concerns and are the 2nd major cause of loss of productive life and death worldwide. These also remain as one of the leading cause of loss of productive life worldwide. Among the death caused by microorganisms $70 \%$ are caused by bacterial infections [1].

A number of important antibiotics including tetracyclines, macrolides, cephalosporins and aminoglycosides

\footnotetext{
* Correspondence: mrkhanqau@yahoo.com

Department of Biochemistry, Faculty of Biological Sciences, Quaid-i-Azam University, Islamabad 45320, Pakistan
}

have been developed for solving major problems of infectious diseases. However, these valuable compounds are now facing a risk of losing their worth because multiple drug resistance has been advanced in plant and human pathogenic microorganisms [2-4]. The global emergence of several microorganisms such as Klebsiella pneumoniae, Haemophilus and Escherichia coli and a variety of $\beta$-lactamase producers are accounting for major therapeutic problems nowadays. These multi-drug resistant strains of $K$. pneumoniae and E. coli are found abundantly in hospitals and isolated from acquired community infections $[4,5]$. Methicillin-resistant 
Staphylococcus aureus (MRSA) is not only impervious to methicillin (originally designed to eradicate penicillinase producing $S$. aureus) but also to other antibiotics such as chloramphenicol, tertracycline, aminoglycosides and lincosamides etc. Increasing resistance in these strains is also observed against disinfectants which is a leading cause of clinically-acquired infections [6], therefore, there is a need to explore plant based therapeutic agents that are effective against MRSA [7, 8]. Candida albicans is also reported to be responsible for causing invasive candidiasis contributing to about $50-70 \%$ of the cases [9]. This present condition has compelled scientists to evaluate novel antimicrobial agents from different sources including medicinal plants $[10,11]$. Antimicrobial testing can be used for discovery of new drugs, epidemiology and their possible therapeutic outcome [12].

One of the known plants reported for its aromatic and medicinal properties is Parrotiopsis jacquemontiana (Decne) Rehder. It is a commonly distributed wild shrub/small tree of about $5 \mathrm{~m}$ tall residing in the forests of Upper Dir, Pakistan. Its vernacular name is Beranj and belongs to the family Hamamelidaceae [13]. Leaves of this plant are reported to have wide use for combatting skin infections, skin eruptions and for treating general body pain $[14,15]$. The leaves are crushed and placed 2-3 days on the wounded area for healing. Oil can be extracted from its stem and placed on the affected area [16]. Up till now, no literature data was found relevant to its biological activities including antibacterial, antifungal, and phytochemical investigation. Therefore, the main objectives of the present study conducted were to evaluate the antibacterial (clinical multidrug resistant strains; MDR), antifungal and phytochemical constituents of the methanol extract of $P$. jacquemontiana and its derived fractions.

\section{Methods}

\section{Collection and identification of plant material}

The leaves of $P$. jacquemontiana were collected from the forests of Upper Dir, Pakistan in the month of May-June 2016. It was recognized by its local name and then taxonomically identified and confirmed by a senior plant taxonomist Syed Afzal Shah of Plant Sciences Department, Quaid-i-Azam University, Islamabad, Pakistan. The voucher specimen (063214) was deposited at the Herbarium of Pakistan, Quaid-i-Azam University, Islamabad, Pakistan.

\section{Preparation of plant material and fractionation}

The collected leaves were cleaned to remove from dust particles and then placed under shade drying for about two to three weeks. The dried plant sample was then ground to a fine texture powder by subjecting it to a 60 -mesh size Willy mill. About $1 \mathrm{~kg}$ of the plant powder was extracted with $5 \mathrm{l}$ of $95 \%$ methanol (thrice) for $72 \mathrm{~h}$ and then filtered with Whatman No. 1 filter paper. The filtrate was combined and concentrated on a rotary evaporator under reduced pressure at $40{ }^{\circ} \mathrm{C}$. For fractionation purpose, a weighed (50 g) portion of the extract (PJM) was suspended in distilled water $(400 \mathrm{ml})$ and exposed to liquid-liquid partition by using different solvents $(400 \mathrm{ml})$ in order to resolve the compounds with escalating polarity. The fractionation by each solvent was carried out thrice. The solvents were used in the order of n-hexane (PJH), chloroform (PJC), ethyl acetate (PJE), and n-butanol (PJB) while the soluble residual aqueous material was termed aqueous fraction (PJA). The respective solvents were again evaporated with rotary evaporator under reduced pressure. The fractions were dried, collected, weighed and stored at $4{ }^{\circ} \mathrm{C}$ until phytochemical and antimicrobial activities were performed.

\section{Screening of phytochemical constituents}

Phytochemical components of PJM and its derived fractions were analyzed qualitatively by using different standardized test procedures [17-21].

\section{Alkaloid detection}

Mayer's test According to this test procedure, $2 \mathrm{ml}$ of concentrated $\mathrm{HCl}$ was added to $2 \mathrm{ml}$ of the respective plant extract samples followed by an addition of few drops of Mayer's reagent. Either formation of white precipitate or green color confirmed the existence of alkaloids in that tested sample.

Hager's test For this test procedure, few drops of Hager's reagent (saturated picric acid solution) added to $2 \mathrm{ml}$ of the respective plant extract. Bright yellow precipitate formation indicated the existence of alkaloids [17].

\section{Anthocyanin and betacyanin detection}

An aliquot of $1 \mathrm{ml}$ of $2 \mathrm{~N} \mathrm{NAOH}$ was added to $2 \mathrm{ml}$ of each plant extract and heated at $100{ }^{\circ} \mathrm{C}$ for about $5 \mathrm{~min}$ to assess the presence of anthocyanin and betacyanin. Bluish green color formation specified the existence of anthocyanin while yellow color specified the existence of betacyanin in the plant samples tested [18].

\section{Anthraquinone detection}

According to [19] few drops of $2 \% \mathrm{HCl}$ were added to the tested plant extracts. Red precipitate formation indicated the existence of anthraquinones in the samples, while another test procedure [17] involved the addition of $1 \mathrm{ml}$ benzene to $1 \mathrm{ml}$ of test sample followed by the addition of $10 \%$ ammonia solution. Red color formation indicated the existence of anthraquinones in the samples. 


\section{Coumarins detection}

A volume of $1 \mathrm{ml}$ of $10 \% \mathrm{NAOH}$ solution was added to $1 \mathrm{ml}$ of the plant samples. Yellow color formation confirmed the existence of coumarins in the tested samples [19].

\section{Flavonoids detection}

Alkaline reagent test According to [18], $1 \mathrm{ml}$ of $2 \mathrm{~N}$ $\mathrm{NAOH}$ solution was added to $1 \mathrm{ml}$ of plant extract samples. Yellow color appearance indicated the existence of flavonoids in the sample.

$\mathbf{F e C l}_{3}$ test Few drops of $\mathrm{FeCl}_{3}$ solution was added to $1 \mathrm{ml}$ of plant extract samples. Blackish red precipitate revealed the existence of flavonoids in the test samples [17].

\section{Glycosides detection}

Keller Killani test A volume of $1 \mathrm{ml}$ of glacial acetic acid was added to $1 \mathrm{ml}$ of plant extract samples and cooled. After cooling, 2 drops of $\mathrm{FeCl}_{3}$ was added followed by careful addition of conc. $\mathrm{H}_{2} \mathrm{SO}_{4}$ along the walls of the test tube. Reddish brown colour ring formed at the junction of two layers indicated the existence of glycosides [17].

\section{Saponin detection}

According to [19], $2 \mathrm{ml}$ of distilled water was added to $2 \mathrm{ml}$ of plant extract sample and shaken vigorously lengthwise for $15 \mathrm{~min}$ in a graduated cylinder. A layer of foam $1 \mathrm{~cm}$ or more thick confirmed the existence of saponins in the test samples.

\section{Tannin detection}

$\mathrm{FeCl}_{3}$ test A volume of $2 \mathrm{ml}$ of $5 \% \mathrm{FeCl}_{3}$ was added to $1 \mathrm{ml}$ of plant extract samples. Appearance of greenish black or dark blue color confirmed the existence of tannins in the test samples [18].

Alkaline reagent test A volume of $2 \mathrm{ml}$ of $1 \mathrm{~N}$ of $\mathrm{NaOH}$ was added to $2 \mathrm{ml}$ of plant extract samples. Appearance of yellow to red color revealed the existence of tannins [17].

Bromine water test Plant extracts were dissolved in $50 \%$ alcohol and filtered. The filtrate was reacted with 3-4 drops of bromine water. Appearance of buff color indicated the existence of condensed tannins in the plant test sample whereas hydrolysable tannins gave no such indication [20].

\section{Terpenoid detection}

An aliquot of $1 \mathrm{ml}$ of $1 \% \mathrm{HCl}$ was added to $2 \mathrm{ml}$ of plant extract samples and left to stand for 5-6 h. Later on, $1 \mathrm{ml}$ of Trim-Hill reagent was added to it and heated in a boiling water bath for 5-10 min. Appearance of bluish green color indicated the existence of terpenoids [17].

\section{Phenol assessment}

Ellagic acid test Few drops of $5 \%$ glacial acetic acid were added to $1 \mathrm{ml}$ of plant extract samples followed by addition of few drops of $5 \% \mathrm{NaNO}_{2}$ solution. Muddy brown color formation revealed the existence of phenols in the test samples [17].

\section{Sterol detection}

Salkowski's test In this test procedure $5 \mathrm{ml}$ of chloroform was added to $2 \mathrm{ml}$ of plant extract samples followed by careful addition of $1 \mathrm{ml}$ of conc. $\mathrm{H}_{2} \mathrm{SO}_{4}$ along the walls of the tube. Reddish brown color in the lower layer indicated the existence of sterols in the test samples [17].

\section{Steroid and Phytosteroid detection}

To $1 \mathrm{ml}$ of plant extract sample, equal volume of chloroform was added. After subjecting the mixture to few drops of conc. $\mathrm{H}_{2} \mathrm{SO}_{4}$, ring formation took place. Appearance of a brown color ring marked the existence of steroids whereas appearance of bluish-brown ring color marked the existence of phytosteroids in the test samples.

\section{Phytosterol detection}

Libermann-Buchard's test Plant extracts were filtered after treating with chloroform. The filtrate obtained was treated with few drops acetic anhydride, boiled and cooled at room temperature. Conc. $\mathrm{H}_{2} \mathrm{SO}_{4}$ was added and formation of brown-color ring at the junction demarcated the existence of phytosterols in the test samples.

\section{Phlobatannins detection}

To a volume of $1 \mathrm{ml}$ plant extract sample, few drops of ammonia solution (10\%) were added. Pink color precipitates designated the existence of Phlobatannins in test samples.

\section{Triterpenoids detection}

$1 \mathrm{ml}$ of Libermann-Buchard Reagent (acetic anhydride + conc. $\mathrm{H}_{2} \mathrm{SO}_{4}$ ) was added to $1.5 \mathrm{ml}$ of plant extract samples. Appearance of bluish-green color marked the existence of triterpenoids in the test samples.

\section{Quinones detection}

$1 \mathrm{ml}$ of conc. $\mathrm{H}_{2} \mathrm{SO}_{4}$ was added to plant extract sample $(1 \mathrm{ml})$. Red color appearance designated the existence of quinones in the test samples. 


\section{Acid detection}

$1 \mathrm{ml}$ plant extract sample was treated with a solution of sodium bicarbonate. Effervescence formation indicated the existence of acids in the test samples.

\section{Vitamin C detection}

DNPH test $1 \mathrm{ml}$ plant test solution was reacted with Dinitrophenyl hydrazine (dissolved in conc. $\mathrm{H}_{2} \mathrm{SO}_{4}$ ). Yellow precipitate formation marked the existence of vitamin $C$ in the test samples.

\section{Protein detection}

Xanthoproteic test The plant extract sample $(1 \mathrm{ml})$ was treated with few drops concentrated Nitric acid according to this procedure test. Yellow color formation indicated the presence of proteins in the test samples.

Biuret test $\mathrm{NAOH}$ solution (40\%) was added in equal volume to $0.5 \mathrm{mg}$ plant extract solution followed by addition of few drops $\mathrm{CUSO}_{4}$ solution (1\%). Violet color appearance in the test samples marked the existence of proteins.

\section{Carbohydrate detection}

Benedict's test Few drops of Benedict's reagent (alkaline solution of cupric-citrate complex) were mixed with test solution samples followed by boiling in water bath. Reddish-brown precipitate formation indicated the existence of carbohydrates in the test samples.

\section{Oils and resins detection}

Filter paper test Plant test samples were applied on filter paper. The development of transparent appearance on filter paper indicated the existence of oils and resins in plant test samples.

\section{Quantitative phytochemical constituent determination} The extract samples of P.jacquemontiana showing the presence of alkaloids, phenols, flavonoids, tannins and saponins in qualitative analysis were further quantified employing standard procedures.

\section{Alkaloid quantification}

Methodology of [22] was followed for the quantitative determination of alkaloids. $1 \mathrm{~g}$ of sample was weighed in a $250 \mathrm{ml}$ beaker and $150 \mathrm{ml} \mathrm{10 \%} \mathrm{acetic} \mathrm{acid} \mathrm{prepared} \mathrm{in}$ ethanol was added to it. The solution mixture was covered and allowed to stand for a time interval of $4 \mathrm{~h}$. After the required time interval, the mixture was filtered and the resultant filtrate was concentrated on waterbath to reduce its volume up to a quarter of its original volume. Conc. $\mathrm{NH}_{4} \mathrm{OH}$ was added to the extract sample dropwise until complete precipitation. The solution was allowed to settle, precipitate collected, washed with dilute
$\mathrm{NH}_{4} \mathrm{OH}$ and filtered. The residue obtained was completely dried and weighed to calculate the percentage of alkaloids in the test sample.

\section{Phenol quantification}

First of all, fat-free sample was prepared by defatting $1 \mathrm{~g}$ sample with $100 \mathrm{ml}$ di-ethyl ether employing soxhlet apparatus for a time interval of $2 \mathrm{~h}$. Phenol quantification was done by utilizing spectrophotometric method. The fat-free sample was boiled for $15 \mathrm{~min}$ with ether $(50 \mathrm{ml})$ for complete extraction of phenolic components. $5 \mathrm{ml}$ extract was pipetted into $50 \mathrm{ml}$-flask, and $10 \mathrm{ml}$ distilled water was added. After this, $2 \mathrm{ml} \mathrm{NH}_{4} \mathrm{OH}$ solution was added followed by addition of $5 \mathrm{ml}$ conc. amyl alcohol. After making samples up to the mark, they were left to react for $30 \mathrm{~min}$ to develop colour which was measured at $505 \mathrm{~nm}$ against standard curve of gallic acid. Results were quantified in the form of GAE (mg of Gallic Acid Equivalents) per gram of dry plant extract/fraction.

\section{Flavonoid quantification}

Procedure of [23] was followed for quantification of flavonoids in the test samples. For this purpose, $1 \mathrm{~g}$ plant sample was repeatedly extracted with $100 \mathrm{ml} \mathrm{80 \%} \mathrm{aque-}$ ous methanol kept at room temperature and finally filtered through Whatman \# 42 filter paper (125 mm). The filtrate was transferred into crucible and left for complete evaporation over water bath. After drying, the sample was weighed until constant weight obtained.

\section{Tannin quantification}

Tannin content was determined by following the methodology of [24] with slight modifications. According to this, $500 \mathrm{mg}$ sample was weighed in $50 \mathrm{ml}$ plastic bottle. $50 \mathrm{ml}$ distilled water was added and left for shaking on mechanical shaker for a time period of $1 \mathrm{~h}$. This was filtered and made up to the mark in $50 \mathrm{ml}$ volumetric flask. $5 \mathrm{ml}$ of filtrate was pipetted out in a test tube and mixed thoroughly with $2 \mathrm{ml} \mathrm{FeCl}_{3}(0.1 \mathrm{M})$ in $\mathrm{HCl}(0.1 \mathrm{~N})$ and potassium ferrocyanide $(0.008 \mathrm{M})$. The absorbance at $120 \mathrm{~nm}$ was measured spectrophotometrically against standard curve of gallic acid. Results were quantified in the form of GAE (mg of Gallic Acid Equivalents) per gram of dry plant extract/fraction [25].

\section{Saponin quantification}

Determination Procedure of [26] was used for saponin quantification. $1 \mathrm{~g}$ plant sample was dispersed in $150 \mathrm{ml}$ of $20 \%$ aqueous ethanol. The suspension was heated for $4 \mathrm{~h}$ on water-bath at $55{ }^{\circ} \mathrm{C}$ with continuous stirring. The mixture after filtration was re-extracted with another $150 \mathrm{ml} \mathrm{20 \%}$ aqueous ethanol. The combined extracts were reduced over water-bath to $40 \mathrm{ml}$ by heating at $90{ }^{\circ} \mathrm{C}$. The concentrate was transferred to separating 
funnel after addition and vigorous shaking with $20 \mathrm{ml}$ diethyl ether. The aqueous layer obtained was collected and ether layer discarded. This purification step was repeated. $50 \mathrm{ml} \mathrm{n}$-butanol was added and combined n-butanol extracts were washed twice with $10 \mathrm{ml}$ aqueous $\mathrm{NACl}$ (5\%). The remaining solution was transferred to water-bath and heated till complete evaporation. After evaporation, samples were dried in oven to achieve a constant weight. Saponin content was calculated as percentage yield of the sample.

\section{Antibacterial screening}

For antibacterial screening total of 19 clinical bacterial strains were tested in this experiment. Bacterial strains comprised of 7 multidrug resistant (MDR) bacterial strains viz. Staphylococcus aureus (3884), Staphylococcus aureus (6301), Staphylococcus aureus (9861), Staphylococcus lugdunensis (6197), Klebsiella pneumoniae (87005) ESBL, Klebsiella pneumoniae (82431), and Escherichia coli (52321). There were 12 other clinical isolates including; Staphylococcus aureus MRSA (12861), Staphylococcus aureus (31414), Staphylococcus aureus (5764), Staphylococcus lugdunensis (4338), Pseudomonas aeruginosa (27853), Coagulase negative staphylococci (12731), Escherichia coli (22244), Klebsiella specie (34529), and Klebsiella pneumoniae (35967) whereas 3 bacterial strains isolated from the environmental setup; Escherichia coli " $a$ ", Escherichia coli " $b$ ", and Klebsiella pneumoniae " $a$ ", tested in this experiment. The bacterial strains were acquired from the Department of Microbiology, Quaid-i-Azam University Islamabad.

For the determination of antibacterial activity all the plant samples were dissolved in DMSO to make a final concentration of $50 \mathrm{mg} / \mathrm{ml}$. Antibacterial activities were carried out by disc diffusion method [27]. All the bacterial strains were cultured overnight in nutrient agar medium (NA) at $37{ }^{\circ} \mathrm{C}$ prior to experimentation. The following day, about $100 \mu \mathrm{l}$ of saline suspension containing $10^{8} \mathrm{CFU} / \mathrm{ml}$ of bacteria were spread on nutrient agar medium plates. The particular test strain inoculum was uniformly distributed on the petri plates by swabbing with sterile cotton swabs in three dimensions to ensure the growth of that particular strain on the plate. Sterile filter paper discs (6 $\mathrm{mm}$ in diameter) were impregnated with $20 \mu \mathrm{l}$ of each test sample $(1000 \mu \mathrm{g} /$ disc $)$, dried and placed over the surface of media. Negative controls were prepared by using the same solvent in which plant extract samples were prepared. The bacterial inoculated plates were incubated at $37{ }^{\circ} \mathrm{C}$ for $24 \mathrm{~h}$. The assays were performed in triplicates against each bacterial strain. After the specified time, diameters of zones of inhibition formed around discs were measured in millimeters $(\mathrm{mm})$ to determine the activity of test samples against different strains
[28]. 8-13 mm: low inhibition; 14-19 mm: moderate inhibition; $\geq 20 \mathrm{~mm}$ : high inhibition [29].

\section{Bacterial MIC and MBC determination}

The MIC (minimal inhibitory concentration) and MBC (minimal bactericidal concentration) was assessed for the effective plant samples tested during the disc diffusion assay. Bacterial tests were performed in nutrient agar broth (NAB) and about 12 h-old bacterial cultures were used and their suspension turbidity was compared with the turbidity of 0.5 McFarland standards. The plant samples were first thoroughly dissolved in $2.5 \%$ DMSO and then diluted to make a concentration $512 \mu \mathrm{g} / \mathrm{ml}$ as the highest concentration tested. Further two-fold serial dilutions were prepared to achieve a concentration ranging from 8 to $512 \mu \mathrm{g} / \mathrm{ml}$ in sterile test tubes. MIC values of the plant samples were calculated against all bacterial strains isolates by a combination of micro-well dilution assay and $p$-Iodonitrotetrazolium chloride $0.2 \%$ (INT) calorimetric assay [30, 31].

Briefly, 96-well plates were prepared by distributing $95 \mu \mathrm{l}$ of nutrient broth into each well followed by $5 \mu \mathrm{l}$ of inoculum. From the primarily formed stock solutions of plant extracts having a concentration $512 \mu \mathrm{g} / \mathrm{ml}$, a $100 \mu \mathrm{l}$ was picked and dispensed into the first wells. Further six consecutive wells downward were dispensed with $100 \mu \mathrm{l}$ each from their serial dilutions and the last well having no compound except adequate amount of nutrient broth, DMSO and $5 \mu \mathrm{l}$ of inoculum, which were used as negative control. The final volume of each well was made up to $200 \mu \mathrm{l}$ only. Cefixime was prepared in nutrient broth at the concentration ranging from 2 to $128 \mu \mathrm{g} / \mathrm{ml}$ and used as positive control standard drug. Sterile plate sealer was used to fully cover the plate and then a plate shaker at the speed of $300 \mathrm{rpm}$ was used to mix the contents of each well for about $20 \mathrm{~s}$. The bacterial inoculated plates were incubated for $24 \mathrm{~h}$ at $37{ }^{\circ} \mathrm{C}$ and $40 \mu \mathrm{l}$ of INT $(0.2 \mathrm{mg} / \mathrm{ml})$ was added to it the next day followed by $30 \mathrm{~min}$ incubation period. Viable bacteria present in the samples turned the yellow dye into a pink colour. MIC was demarcated as the sample concentration which prohibited the medium to change colour thus demonstrating inhibition of bacterial growth.

For MBC determination broth was picked from each well and spread on nutrient agar medium for a time interval of $24 \mathrm{~h}$ at $37{ }^{\circ} \mathrm{C}$. The $\mathrm{MBC}$ was defined as the least possible concentration of the plant extract samples to completely kill the inoculated microorganisms [32]. Negative control included NAB with DMSO whereas cefixime served as positive control. Furthermore, MBC/ MIC ratio was calculated against each bacterial strain depicting whether the antibacterial effect is bactericidal or bacteriostatic [33]. 


$$
\begin{aligned}
& 1 \leq(\mathrm{MBC} / \mathrm{MIC}) \leq 2=\text { Bactericidal effect } \\
& 4 \leq(\mathrm{MBC} / \mathrm{MIC}) \leq 16=\text { Bacteriostatic effect }
\end{aligned}
$$

\section{Antifungal screening}

The antifungal and anti-yeast activity of the plant samples was estimated by disc diffusion assay [27]. Prior to experimentation, the fungal and yeast strain was cultured overnight in Sabouraud dextrose agar (SDA) medium at $30{ }^{\circ} \mathrm{C}$. The following day, $100 \mu \mathrm{l}$ of distilled water suspension containing $10^{4}$ spore $/ \mathrm{ml}$ of fungus and $10^{6} \mathrm{CFU} / \mathrm{ml}$ of yeast were spread on Sabouraud dextrose agar medium plates. Fungal isolates included 7 fungal strains viz. Aspergillus niger (ATCC 6275), Mucor piriformis (ATCC 52554), Fusarium solani (ATCC 36031), Aspergillus flavus (ATCC 204304), Wickerhamomyces anomalus (KU949595), Wickerhamomyces anomalus (KU949596), Deboromyces hansenii and a yeast Candida albicans (90028) obtained from the American Type Culture Collection (ATCC) or from the environmental setup. The fungal strains were acquired from the Department of Microbiology, Quaid-i-Azam University Islamabad. Briefly, sterile discs $6 \mathrm{~mm}$ diameter containing $1000 \mu \mathrm{g} / \mathrm{disc}$ of each extract sample was placed over the surface of media. DMSO was used as the negative control. The fungal and yeast inoculated plates were incubated at $28{ }^{\circ} \mathrm{C}$ for $72 \mathrm{~h}$ and $48 \mathrm{~h}$, respectively. The antifungal and anti-yeast activity was assessed in terms of inhibition zones $(\mathrm{mm})$ after a specified period [28]. The experiment was performed in triplicate. 8-13 mm: low inhibition; $14-19 \mathrm{~mm}$ : moderate inhibition; $\geq 20 \mathrm{~mm}$ : high inhibition [29].

\section{Fungal MIC and MFC determination}

The MIC (minimal inhibitory concentration) and MFC (minimal fungicidal concentration) were determined for the effective test samples. The media used for MIC and MFC determination was Sabouraud dextrose broth (SDB). Fungal cultures and concentration of the test samples used were similar as above for bacterial studies [30, 31]. For determination of fungal MIC, the inoculated plates were incubated for $48 \mathrm{~h}$ at $25-28{ }^{\circ} \mathrm{C}$. Absorbance was taken at $600 \mathrm{~nm}$ by subjecting the plate to a universal microplate reader and microbial growth was determined. The MIC was defined to be the lowest possible concentration of the plant extract samples under study to clearly inhibit visible growth of microorganisms. To determine the MFC, broth was picked from each well and spread/plated on Sabouraud dextrose agar medium for $48 \mathrm{~h}$ at $25-28{ }^{\circ} \mathrm{C}$. The MFC was defined as the least possible concentration of the plant extract samples to completely kill the inoculated microorganisms [32]. These assays were performed in triplicates. Negative control included SDB medium with DMSO while clotrimazole served as positive control standard. Furthermore, MFC/MIC ratio was calculated against each fungal and yeast strain depicting whether the antifungal effect is fungicidal or fungistatic [33].

$$
\begin{aligned}
& 1 \leq(\mathrm{MFC} / \mathrm{MIC}) \leq 2=\text { Fungicidal effect } \\
& 4 \leq(\mathrm{MFC} / \mathrm{MIC}) \leq 16=\text { Fungistatic effect }
\end{aligned}
$$

\section{Statistical analysis}

The data was expressed as mean \pm standard deviation. All the experimental assays were performed in triplicate.

\section{Results}

\section{Plant yield and fractionation}

The extraction yield of methanol extract of $P$. jaqcuemontiana leaves (PJM) was approximately $95 \mathrm{~g}$. Upon fractionation $(50 \mathrm{~g})$ five different fractions $(\mathrm{PJH}$, PJC, PJE, PJB, and PJA) were formed and their percentage extraction yield was $30,2,36,12$ and $18 \%$ as presented in Table 1 , respectively .

\section{Phytochemical qualitative study}

The phytochemical analysis study of PJM and its derived fractions revealed important medicinal constituents present within the sample as illustrated in Table 2. Qualitative analysis confirmed the existence of coumarins, flavonoids, tannins, alkaloids, sterols, betacyanins, triterpenoids, phlobatannins, steroids, phenols, glycosides, saponins, quinones, acid, vitamin $C$, proteins, oils and resins in PJM. Presence of anthraquinones, phytosteroids, carbohydrates and anthocyanin were not established in PJM. Alkaloids, triterpenoids, quinones, acid, vitamin $\mathrm{C}$, proteins, oils and resins were the classes present in PJH. PJC comprised of nearly all chemical classes studied except sterols, steroids, phlobatannins, phytosterols, saponins, phytosteroids, carbohydrates, anthraquinone and anthocyanin. Coumarins, alkaloids, saponins, tannins, phlobatannins, steroids, phytosterols, glycosides, quinones, acid, vitamin C, proteins, carbohydrates, sterols, oils and resins marked their existence in PJE. Terpenoids, triterpenoids, anthraquinones, phenols, phytosteroids, sterols and anthocyanin were absent in PJB whereas all other remaining chemical classes were present. PJA marked the absence of terpenoids, triterpenoids, anthraquinones, phlobatannins, phenols, alkaloids, carbohydrates, phytosteroids, saponins and anthocyanin and presence of coumarins, flavonoids, tannins, steroids, sterols, phytosterols, glycosides, quinones, acid, vitamin C, proteins, betacyanin, oils and resins as depicted in Table 2, respectively.

\section{Phytochemical quantitative study}

Based on preliminary phytochemical qualitative test results obtained, the quantitative estimation of some major phytochemicals including alkaloids, flavonoids, 
Table 1 Extraction yield of $P$. jacquemontiana methanol extract and its corresponding fractions

\begin{tabular}{ll}
\hline Plant sample & Percentage yield (\%) \\
\hline PJM & $50^{\text {a }}$ \\
PJH & 30 \\
PJC & 2 \\
PJE & 36 \\
PJB & 12 \\
PJA & 18
\end{tabular}

PJM (P. jacquemontiana methanol fraction), PJH (P. jacquemontiana n-hexane fraction), PJC (P. jacquemontiana chloroform fraction), PJE (P. jacquemontiana ethyl acetate fraction), PJB (P. jacquemontiana butanol fraction), PJA (P. jacquemontiana aqueous fraction)

aYield of PJM in grams based on dry powder weight; fraction yield dependent upon PJM yield

phenols, saponins and tannins were carried out in those plant extract samples where their presence was marked positive. Comparative quantitative estimation of different PJM derived fractions is shown in Table 3. Highest alkaloid percentage yield/g of sample was presented by PJE $(22.5 \pm 0.5)$ consecutively followed by PJM $(12.5 \pm 0.17)$. PJC and PJB displayed alkaloid percentage values of 7.7 \pm 0.14 and $5.7 \pm 0.36$, respectively whereas least value was shown by $\mathrm{PJH}(0.71 \pm 0.21)$ having minimal alkaloid percentage yield/g of sample. Flavonoid percentage yield/g of sample was marked highest in PJM $(7.4 \pm 0.14)$ followed by PJB $(6.6 \pm 0.42)$, PJA $(4.6 \pm 0.11)$ and PJC $(3.5 \pm 0.07)$, respectively. Saponin content expressed as percentage yield/g of sample exhibited maximum values for PJE $(5.5 \pm 0.28)$ followed closely by PJM $(4.4 \pm 0.42)$ whereas minimal values was shown by PJB $(1.8 \pm 0.11)$, respectively. Apart from this, phenols were depicted maximum in PJM showing a value of $611.5 \pm 2.18 \mathrm{mg}$ GAE/ $g$ of extract compared to PJC showing a value of $342.8 \pm 1.69 \mathrm{mg} \mathrm{GAE} / \mathrm{g}$ of extract whereas tannins were minimum in PJA $(110.5 \pm 0.74 \mathrm{mg}$ GAE/ g of extract) followed by PJM (159.4 $\pm 1.85 \mathrm{mg}$ GAE/ $\mathrm{g}$ of extract) and maximum in PJE $(244.3 \pm 2.03 \mathrm{mg} \mathrm{GAE} / \mathrm{g}$ of extract), closely followed by PJB $(231.6 \pm 1.93 \mathrm{mg} \mathrm{GAE} / \mathrm{g}$ of extract) and PJC (203.8 $\pm 2.67 \mathrm{mg} \mathrm{GAE} / \mathrm{g}$ of extract), respectively.

\section{Antibacterial activity of $P$. jacquemontiana}

In vitro antibacterial activity of $P$. jacquemontiana was evaluated qualitatively and quantitatively against the selected microorganisms by the manifestation or absence of zones of inhibition, inhibition diameters, MIC and $\mathrm{MBC}$ values. According to the initial bacterial screening results specified in Table 4, the methanol fraction of $P$. jacquemontiana (PJM) showed strong activity against all the bacterial strains under study. The obtained results showed the variability of antibacterial potential of PJM fraction towards different gram positive and gram
Table 2 Qualitative phytochemical analysis of $P$. jacquemontiana leaves methanol extract and its derived fractions

\begin{tabular}{|c|c|c|c|c|c|c|}
\hline Phytochemical & PJM & PJH & PJC & PJE & PJB & PJA \\
\hline Terpenoids & + & + & + & - & - & - \\
\hline Triterpenoids & + & + & + & - & - & - \\
\hline Coumarins & + & - & + & + & + & + \\
\hline \multicolumn{7}{|l|}{ Flavonoids } \\
\hline Alkaline reagent test & + & - & + & - & + & + \\
\hline $\mathrm{FeCl}_{3}$ test & + & - & + & - & + & + \\
\hline \multicolumn{7}{|l|}{ Tannins } \\
\hline Alkaline reagent test & + & - & + & + & + & + \\
\hline $\mathrm{FeCl}_{3}$ test & + & - & + & + & + & + \\
\hline Condensed Tannins & + & - & - & + & + & + \\
\hline Hydrolysable tannins & - & + & + & - & - & - \\
\hline Phlobatannins & + & - & - & + & + & - \\
\hline Steroids & + & - & - & + & + & + \\
\hline Phytosteroids & - & - & - & + & + & + \\
\hline Anthraquinones & - & - & - & - & - & - \\
\hline Phenols & + & - & + & - & - & - \\
\hline \multicolumn{7}{|l|}{ Alkaloids } \\
\hline Mayer's test & + & + & + & + & + & - \\
\hline Hager's test & + & + & + & + & + & - \\
\hline Glycosides & + & + & + & + & + & + \\
\hline Saponins & + & - & - & + & + & - \\
\hline Sterols & + & - & - & + & - & + \\
\hline Quinones & + & + & + & + & + & + \\
\hline Acids & + & + & + & + & + & + \\
\hline Vitamin C & + & + & + & + & + & + \\
\hline \multicolumn{7}{|l|}{ Proteins } \\
\hline Xanthoproteic test & + & + & + & + & + & + \\
\hline Biuret test & + & + & + & + & + & + \\
\hline Carbohydrates & - & - & - & + & + & - \\
\hline Oils and Resins & + & + & + & + & + & + \\
\hline Anthocyanin & - & - & - & - & - & - \\
\hline Betacyanin & + & - & + & - & + & + \\
\hline
\end{tabular}

PJM methanol extract of $P$. jacquemontiana leaves, $P J H$ n-hexane fraction of PJM, PJC chloroform fraction of PJM; PJE ethyl acetate fraction of PJM, PJB n-butanol fraction of PJM, PJA residual aqueous fraction of PJM. (+) constituent present, (-) constituent absent

negative selected microorganisms. The most sensitive bacterial strain proved to be Staphylococcus lugdenesis, a gram positive MDR (6197) followed by a gram negative MDR, ESBL-Klebsiella pneumoniae (87005) displaying zones of inhibition $35.5 \pm 1.32 \mathrm{~mm}$ and $35.33 \pm 0.57 \mathrm{~mm}$, respectively. Least activity was shown against strain Klebsiella pneumoniae (35967) exhibiting a zone diameter of $22.16 \pm 0.76 \mathrm{~mm}$. PJH and PJC showed activity against nearly all tested bacterial strains excluding Escherichia coli 
Table 3 Quantitative phytochemical analysis of $P$. jacquemontiana leaves methanol extract and its derived fractions

\begin{tabular}{|c|c|c|c|c|c|}
\hline \multicolumn{4}{|c|}{ Percentage (\%) yield per gram } & \multicolumn{2}{|c|}{ mg of GAE/ $g$ of extract } \\
\hline Plant extracts & Alkaloids & Flavonoids & Saponins & Phenols & Tannins \\
\hline PJM & $12.5 \pm 0.17$ & $7.4 \pm 0.14$ & $4.4 \pm 0.42$ & $611.5 \pm 2.18$ & $159.4 \pm 1.85$ \\
\hline PJH & $0.71 \pm 0.21$ & NT & NT & NT & NT \\
\hline PJC & $7.7 \pm 0.14$ & $3.5 \pm 0.07$ & NT & $342.8 \pm 1.69$ & $203.8 \pm 2.67$ \\
\hline PJE & $22.5 \pm 0.5$ & NT & $5.5 \pm 0.28$ & NT & $244.3 \pm 2.03$ \\
\hline PJB & $5.7 \pm 0.36$ & $6.6 \pm 0.42$ & $1.8 \pm 0.11$ & NT & $231.6 \pm 1.93$ \\
\hline PJA & NT & $4.6 \pm 0.11$ & NT & NT & $110.5 \pm 0.74$ \\
\hline
\end{tabular}

Mean \pm SD $(n=3)$, PJM P. jacquemontiana methanol fraction, $P J H$ P. jacquemontiana $n$-hexane fraction, $P J C$. . jacquemontiana chloroform fraction, PJE P. jacquemontiana ethyl acetate fraction, PJB P. jacquemontiana butanol fraction, PJA P. jacquemontiana aqueous fraction, NT Not Tested

"a", Klebsiella pneumoniae and Escherichia coli "b" (all isolated from environmental setup). PJC also failed to show activity against Staphylococcus lugdenesis (4338). The highest and lowest zone inhibition diameter presented by $\mathrm{PJH}$ was $34 \pm 1.0 \mathrm{~mm}$ against MDR
ESBL-Klebsiella pneumoniae (87005) and 13.16 \pm $0.28 \mathrm{~mm}$ against strain Escherichia coli (22244), respectively. The most sensitive microorganism tested against PJC was Staphylococcus aureus (31414), exhibiting a zone of inhibition $30.33 \pm 1.44 \mathrm{~mm}$ and the least

Table 4 Antibacterial screening of $P$. jacquemontiana extract against gram positive and gram negative bacteria

\begin{tabular}{|c|c|c|c|c|c|c|}
\hline \multirow[b]{2}{*}{ Isolate (s) } & \multicolumn{6}{|c|}{ Extract/Fractions (1000 $\mu \mathrm{g} / \mathrm{disc})$} \\
\hline & PJM & $\mathrm{PJH}$ & PJC & PJE & PJB & PJA \\
\hline \multicolumn{7}{|l|}{ Staphylococcus aureus } \\
\hline MDR (6301) & $24.16 \pm 1.25$ & $27.66 \pm 0.28$ & $25.16 \pm 1.04$ & $28 \pm 1.32$ & $24.16 \pm 1.04$ & - \\
\hline MDR (3884) & $31.16 \pm 2.02$ & $29 \pm 1.0$ & $24.83 \pm 0.28$ & $26.5 \pm 0.5$ & $28.66 \pm 0.28$ & - \\
\hline MRSA (12861) & $22.5 \pm 1.32$ & $23.16 \pm 1.25$ & $25 \pm 0.5$ & $26 \pm 1.0$ & $25.33 \pm 1.04$ & - \\
\hline MDR (9861) & $25.16 \pm 0.04$ & $22.5 \pm 0.5$ & $26.33 \pm 1.25$ & $26.5 \pm 0.86$ & $28.83 \pm 0.76$ & - \\
\hline$(5764)$ & $29 \pm 1.0$ & $26 \pm 1.0$ & $27.33 \pm 0.57$ & $27 \pm 1,0$ & $23.5 \pm 0.5$ & - \\
\hline (31414) & $26 \pm 1.0$ & $32 \pm 0.86$ & $30.33 \pm 1.44$ & $22.5 \pm 0.5$ & $25 \pm 1.0$ & - \\
\hline \multicolumn{7}{|c|}{ Staphylococcus lugdenesis } \\
\hline MDR (6197) & $35.5 \pm 1.32$ & $28.5 \pm 0.5$ & $24.83 \pm 1.04$ & $26.5 \pm 0.5$ & $26.83 \pm 0.28$ & - \\
\hline (4338) & $24 \pm 1.0$ & $18 \pm 1.0$ & - & $25.66 \pm .57$ & $20.5 \pm 0.86$ & - \\
\hline \multicolumn{7}{|l|}{ Escherichia coli } \\
\hline MDR (52331) & $27.83 \pm 0.76$ & $28.83 \pm 0.28$ & $24.83 \pm 1.25$ & $24.33 \pm 0.57$ & $31.16 \pm 0.76$ & - \\
\hline (22244) & $28 \pm 0.5$ & $13.16 \pm 0.28$ & $14 \pm 1.0$ & $27.83 \pm 0.76$ & $23.5 \pm 0.86$ & - \\
\hline "a" & $23.5 \pm 0.5$ & - & - & $24.16 \pm 0.76$ & $18.33 \pm 1.04$ & - \\
\hline$" b "$ & $24.5 \pm 0.5$ & - & - & $25.66 \pm 0.28$ & $19 \pm 1.0$ & - \\
\hline \multicolumn{7}{|l|}{ Klebsiella pneumoniae } \\
\hline MDR (82431) & $30 \pm 1.0$ & $26 \pm 2.0$ & $26.66 \pm 0.28$ & $25.16 \pm 0.28$ & $33.33 \pm 0.57$ & - \\
\hline ESBL MDR (87005) & $35.33 \pm 0.57$ & $34 \pm 1.0$ & $29.5 \pm 0.5$ & $26 \pm 1.0$ & $28.16 \pm 0.76$ & - \\
\hline (34529) & $27.83 \pm 0.28$ & $17.16 \pm 1.04$ & $18 \pm 1.0$ & $21.83 \pm 1.04$ & $20 \pm 1.0$ & - \\
\hline$(35967)$ & $22.16 \pm 0.76$ & - & - & $20.83 \pm 1.04$ & $19 \pm 0.86$ & - \\
\hline "a" & $26 \pm 2.0$ & - & - & $23.83 \pm 0.57$ & $19 \pm 0.5$ & - \\
\hline \multicolumn{7}{|c|}{ Pseudomonas aeruginosa } \\
\hline (27853) & $25.16 \pm 0.76$ & $21.5 \pm 0.5$ & $14 \pm 2.0$ & $19.66 \pm 1.52$ & $18.33 \pm 0.57$ & - \\
\hline \multicolumn{7}{|c|}{ Coagulase negative staphylococci } \\
\hline$(12731)$ & $28 \pm 2.0$ & $27.33 \pm 0.57$ & $22 \pm 1.0$ & $25.16 \pm 1.04$ & $26.16 \pm 0.76$ & - \\
\hline
\end{tabular}

Zone of inhibition $(\mathrm{mm})$ are expressed as mean $\pm \mathrm{SD}(\mathrm{n}=3) .8-13 \mathrm{~mm}$ : low inhibition; 14-19 mm: moderate inhibition; $\geq 20 \mathrm{~mm}$ : high inhibition. -: no zone of inhibition; $N T$ not tested, PJM methanol extract of $P$. jacquemontiana leaves, PJH: n-hexane fraction of PJM, PJC chloroform fraction of PJM, PJE ethyl acetate fraction of PJM, PJB n-butanol fraction of PJM, PJA residual aqueous fraction of PJM 
sensitive strain was Escherichia coli (22244) and Pseudomonas aeruginosa (27853) both having similar zone of inhibition; $14 \pm 1.0 \mathrm{~mm}$ and $14 \pm 2.0 \mathrm{~mm}$, respectively. Ethyl acetate fraction of $P$. jacquemontiana (PJE) exhibited strong antibacterial activity against all tested microorganisms displaying maximum zone of inhibition $28 \pm$ $1.32 \mathrm{~mm}$ against a gram positive MDR Staphylococcus aureus (6301) and minimum zone of inhibition 19.66 \pm $1.52 \mathrm{~mm}$ against Pseudomonas aeruginosa (27853). Butanol fraction of the plant (PJB) inhibited all bacterial test organisms showing maximum potency $33.33 \pm 0.57 \mathrm{~mm}$ against gram negative MDR Klebsiella pneumoniae (82431) and least potency $18.33 \pm 0.57 \mathrm{~mm}$ against Pseudomonas aeruginosa (27853). Aqueous fraction of the plant (PJA) was tested against all selected microorganisms but it did not show satisfactory zones of inhibition.

\section{MIC and MBC of $P$. jacquemontiana}

The MIC and MBC values of PJM against 19 bacterial strains examined showed to range between 8 and $64 \mu \mathrm{g} /$ $\mathrm{ml}$ and $32-256 \mu \mathrm{g} / \mathrm{ml}$, respectively (Tables 5 and 6). PJH showed an MIC and MBC value ranging between 8 and $128 \mu \mathrm{g} / \mathrm{ml}$ and 64-256 $\mu \mathrm{g} / \mathrm{ml}$. PJC indicated an MIC value range of $32-512 \mu \mathrm{g} / \mathrm{ml}$ and an $\mathrm{MBC}$ value in the range of $128-512 \mu \mathrm{g} / \mathrm{ml}$, respectively. PJE almost similar to PJM specified its MIC value ranging $8-64 \mu \mathrm{g} / \mathrm{ml}$ and MBC ranging 32-128 $\mu \mathrm{g} / \mathrm{ml}$. PJB designated its $\mathrm{MIC}$ and MBC value falling in the range of $8-512 \mu \mathrm{g} / \mathrm{ml}$ and 64-512 $\mu \mathrm{g} / \mathrm{ml}$, respectively. Cefixime exhibited an MIC value in the range of $2-128 \mu \mathrm{g} / \mathrm{ml}$ and an $\mathrm{MBC}$ value ranging between 8 and $128 \mu \mathrm{g} / \mathrm{ml}$. MBC/MIC was also calculated for each extract tested against the bacterial strains.

\section{Antifungal activity of $P$. jacquemontiana}

Antifungal activity of all the fractions of $P$. jacquemontiana evaluated by in vitro disc diffusion method against 7 fungal and 1 yeast strain indicated in Table 7. Zones of inhibition were formed and their diameters were measured in $\mathrm{mm}$ against selected microorganisms in 3 fractions of the plant. PJM, PJE and PJB showed significant zone of inhibition whereas PJH, PJC and PJA did not show any activity. The most susceptible microorganism towards PJM was Aspergillus flavus (ATCC 204304) giving a zone of inhibition $29 \pm 1.0 \mathrm{~mm}$ while the least susceptible was Fusarium solani (ATCC 36031) with inhibition zone of $20 \pm 1.25 \mathrm{~mm}$. PJE inhibited the growth of Wickerhamomyces anomalus (KU949595) at its highest by forming a diametric zone of inhibition $28 \pm 1.0 \mathrm{~mm}$ while the minimum zone $18.66 \pm$ $0.28 \mathrm{~mm}$ was formed against Mucor piriformis (ATCC 52554). In case of PJB, the most sensitive strain tested against it was Candida albicans, $25.83 \pm 0.28 \mathrm{~mm}$ while the
Table $5 \mathrm{MIC}$ and MBC of $P$. jacquemontiana extracts against gram positive and gram negative bacteria

\begin{tabular}{|c|c|c|c|c|c|c|c|c|c|}
\hline \multicolumn{10}{|c|}{ Extract/Fractions $(\mu \mathrm{g} / \mathrm{ml})$} \\
\hline \multirow[b]{2}{*}{ Isolate(s) } & \multicolumn{3}{|l|}{ PJM } & \multicolumn{3}{|l|}{ PJH } & \multicolumn{3}{|l|}{ PJC } \\
\hline & $\overline{M I C}$ & $\mathrm{MBC}$ & $\begin{array}{l}\mathrm{MBC/} \\
\mathrm{MIC}\end{array}$ & $\overline{M I C}$ & MBC & $\begin{array}{l}\mathrm{MBCl} \\
\mathrm{MIC}\end{array}$ & $\overline{\mathrm{MIC}}$ & $\mathrm{MBC}$ & $\begin{array}{l}\mathrm{MBC/} \\
\mathrm{MIC}\end{array}$ \\
\hline \multicolumn{10}{|c|}{ Staphylococcus aureus } \\
\hline $\begin{array}{l}\text { MDR } \\
\text { (6301) }\end{array}$ & 32 & 64 & 02 & 64 & 256 & 04 & 128 & 512 & 04 \\
\hline $\begin{array}{l}\text { MDR } \\
\text { (3884) }\end{array}$ & 16 & 64 & 04 & 128 & 256 & 02 & 128 & 256 & 02 \\
\hline $\begin{array}{l}\text { MRSA } \\
(12861)\end{array}$ & 08 & 32 & 04 & 16 & 128 & 08 & 32 & 128 & 04 \\
\hline $\begin{array}{l}\text { MDR } \\
(9861)\end{array}$ & 32 & 64 & 02 & 32 & 128 & 04 & 128 & 256 & 02 \\
\hline$(5764)$ & 16 & 128 & 08 & 128 & 256 & 02 & 64 & 256 & 04 \\
\hline (31414) & 08 & 32 & 04 & 16 & 128 & 08 & 32 & 256 & 08 \\
\hline \multicolumn{10}{|c|}{ Staphylococcus lugdenesis } \\
\hline $\begin{array}{l}\text { MDR } \\
(6197)\end{array}$ & 32 & 128 & 04 & 64 & 128 & 02 & 512 & 512 & 01 \\
\hline (4338) & 16 & 64 & 04 & 64 & 256 & 04 & - & - & - \\
\hline \multicolumn{10}{|c|}{ Escherichia coli } \\
\hline $\begin{array}{l}\text { MDR } \\
(52331)\end{array}$ & 32 & 128 & 04 & 64 & 128 & 02 & 256 & 512 & 02 \\
\hline (22244) & 08 & 64 & 08 & 32 & 64 & 02 & 64 & 256 & 04 \\
\hline "a" & 08 & 32 & 04 & - & - & - & - & - & - \\
\hline "b" & 08 & 32 & 04 & - & - & - & - & - & - \\
\hline
\end{tabular}

Klebsiella pneumoniae

$\begin{array}{lccccccccc}\text { MDR } & 64 & 256 & 04 & 128 & 512 & 04 & 128 & 512 & 04 \\ (82431) & & & & & & & & & \\ \begin{array}{l}\text { ESBL MDR } \\ (87005)\end{array} & 16 & 64 & 04 & 64 & 256 & 04 & 256 & 512 & 02 \\ (34529) & 08 & 32 & 04 & 08 & 64 & 08 & 32 & 128 & 04 \\ (35967) & 08 & 32 & 04 & - & - & - & - & - & - \\ " a " & 08 & 64 & 08 & - & - & - & - & - & -\end{array}$

Pseudomonas aeruginosa

$\begin{array}{llllllllll}(27853) & 08 & 64 & 08 & 32 & 128 & 04 & 128 & 256 & 02\end{array}$

Coagulase negative staphylococci

$\begin{array}{llllllllll}(12731) & 64 & 128 & 02 & 64 & 256 & 04 & 128 & 512 & 04\end{array}$

$M I C$ minimum inhibitory concentration, $M B C$ minimum bactericidal concentration, PJM methanol extract of $P$. jacquemontiana leaves, $P J H$ n-hexane fraction of PJM, PJC chloroform fraction of PJM; -: no zone of inhibition

least sensitive proved to be Aspergillus flavus (ATCC 204304) forming a diameter of $15.16 \pm 1.04 \mathrm{~mm}$.

\section{MIC and MFC of $P$. jacquemontiana}

The MIC and MFC values of three fractions (PJM, PJE and $\mathrm{PJB}$ ) of $P$. jacquemontiana and clotrimazole were evaluated as shown in Table 8. PJM presented strongest antifungal activity against the test strains hence 
Table 6 MIC and MBC of $P$. jacquemontiana extracts and cefixime against gram positive and gram negative bacteria

\begin{tabular}{|c|c|c|c|c|c|c|c|c|c|}
\hline \multirow[b]{3}{*}{ Clinical Isolate(s) } & \multicolumn{6}{|c|}{ Extract/Fractions $(\mu \mathrm{g} / \mathrm{ml})$} & \multirow{2}{*}{\multicolumn{3}{|c|}{$\begin{array}{l}\text { Antibiotic used }(\mu \mathrm{g} / \mathrm{ml}) \\
\text { Cefixime }\end{array}$}} \\
\hline & \multicolumn{3}{|l|}{ PJE } & \multicolumn{3}{|l|}{ PJB } & & & \\
\hline & MIC & $M B C$ & $\mathrm{MBC} / \mathrm{MIC}$ & MIC & MBC & $\mathrm{MBC} / \mathrm{MIC}$ & $\mathrm{MIC}$ & MBC & $\mathrm{MBC} / \mathrm{MIC}$ \\
\hline \multicolumn{10}{|l|}{ Staphylococcus aureus } \\
\hline MDR (6301) & 32 & 64 & 02 & 128 & 256 & 02 & 16 & 64 & 04 \\
\hline MDR (3884) & 08 & 32 & 04 & 64 & 256 & 04 & 08 & 16 & 02 \\
\hline MRSA (12861) & 08 & 64 & 08 & 32 & 128 & 04 & 64 & 64 & 01 \\
\hline MDR (9861) & 32 & 128 & 04 & 64 & 128 & 02 & 64 & 128 & 02 \\
\hline$(5764)$ & 32 & 128 & 04 & 64 & 256 & 04 & 32 & 64 & 02 \\
\hline (31414) & 16 & 64 & 04 & 08 & 64 & 08 & 08 & 16 & 02 \\
\hline \multicolumn{10}{|c|}{ Staphylococcus lugdenesis } \\
\hline MDR (6197) & 32 & 128 & 04 & 512 & 512 & 01 & 32 & 32 & 01 \\
\hline (4338) & 16 & 64 & 04 & 32 & 128 & 04 & 08 & 32 & 04 \\
\hline \multicolumn{10}{|l|}{ Escherichia coli } \\
\hline MDR (52331) & 64 & 128 & 02 & 128 & 128 & 01 & 128 & 128 & 01 \\
\hline (22244) & 08 & 32 & 04 & 16 & 64 & 04 & 16 & 32 & 02 \\
\hline "a" & 08 & 64 & 08 & 32 & 128 & 04 & 16 & 32 & 02 \\
\hline$" b "$ & 08 & 64 & 08 & 32 & 128 & 04 & 08 & 32 & 04 \\
\hline \multicolumn{10}{|l|}{ Klebsiella pneumoniae } \\
\hline MDR (82431) & 32 & 256 & 08 & 32 & 128 & 04 & 128 & 128 & 01 \\
\hline ESBL MDR (87005) & 16 & 64 & 04 & 32 & 256 & 08 & 64 & 128 & 02 \\
\hline (34529) & 08 & 32 & 04 & 08 & 64 & 08 & 08 & 16 & 02 \\
\hline (35967) & 08 & 64 & 08 & 16 & 128 & 08 & 64 & 128 & 02 \\
\hline$" a "$ & 08 & 64 & 08 & 16 & 64 & 04 & 02 & 08 & 04 \\
\hline \multicolumn{10}{|c|}{ Pseudomonas aeruginosa } \\
\hline (27853) & 16 & 64 & 04 & 08 & 128 & 16 & 08 & 64 & 08 \\
\hline \multicolumn{10}{|c|}{ Coagulase negative staphylococci } \\
\hline$(12731)$ & 32 & 128 & 04 & 32 & 128 & 04 & 64 & 128 & 02 \\
\hline
\end{tabular}

MIC minimum inhibitory concentration, $M B C$ minimum bactericidal concentration, $P J E$ ethyl acetate fraction of PJM, PJB n-butanol fraction of PJM, PJA residual aqueous fraction of PJM

Table 7 Antifungal screening of $P$. jacquemontiana extract/fractions

\begin{tabular}{|c|c|c|c|c|c|c|}
\hline \multirow[b]{2}{*}{ Fungal isolates } & \multicolumn{6}{|c|}{ Extract/fractions (1000 ㅆg/disc) } \\
\hline & PJM & PJH & PJC & PJE & PJB & PJA \\
\hline F. solani ATCC 36031 & $20.33 \pm 1.25$ & - & - & $24.83 \pm 1.04$ & $17.33 \pm 1.52$ & - \\
\hline A. niger ATCC 6275 & $22.66 \pm 2.08$ & - & - & $21.33 \pm 1.52$ & $23.66 \pm .57$ & - \\
\hline A. flavus ATCC 204304 & $29 \pm 1.0$ & - & - & $23.33 \pm 1.25$ & $15.16 \pm 1.04$ & - \\
\hline M. piriformis ATCC 52554 & $26.66 \pm 0.57$ & - & - & $18.66 \pm 0.28$ & $24 \pm 2.0$ & - \\
\hline C. albicans (90028) & $23.33 \pm 1.25$ & - & - & $25.5 \pm 0.5$ & $25.83 \pm 0.28$ & - \\
\hline D. hansenii & $25 \pm 1.0$ & - & - & $26.83 \pm 0.76$ & $21.66 \pm 0.28$ & - \\
\hline W. anomalus (KU949596) & $27.33 \pm 0.76$ & - & - & $25.16 \pm 1.60$ & $22.5 \pm 1.32$ & - \\
\hline W. anomalus (KU949595) & $25.33 \pm 1.52$ & - & - & $28 \pm 1.0$ & $19.83 \pm 1.25$ & - \\
\hline
\end{tabular}

Zone of inhibition $(\mathrm{mm})$ are expressed as mean $\pm \mathrm{SD}(\mathrm{n}=3) .8-13 \mathrm{~mm}$ : low inhibition; 14-19 mm: moderate inhibition; $\geq 20 \mathrm{~mm}$ : high inhibition. -: no zone of inhibition. PJM methanol extract of $P$. jacquemontiana leaves, $P J H$ n-hexane fraction of PJM, PJC chloroform fraction of PJM, PJE ethyl acetate fraction of PJM, PJB n-butanol fraction of PJM, PJA residual aqueous fraction of PJM 
displaying more minimal MIC and MFC values compared to the other fractions. It's MIC and MFC values ranged within 8-64 $\mu \mathrm{g} / \mathrm{ml}$ and 32-256 $\mu \mathrm{g} / \mathrm{ml}$. PJE fraction showed almost similar results displaying an MIC in the range of 8-64 $\mu \mathrm{g} / \mathrm{ml}$ whereas MFC ranging from 32 to $512 \mu \mathrm{g} / \mathrm{ml}$ was presented. PJB exhibited an MIC and MFC in the range of $32-128 \mu \mathrm{g} / \mathrm{ml}$ and $64-512 \mu \mathrm{g} / \mathrm{ml}$, respectively. MIC/MFC values were also calculated for each plant extract tested against the fungal species.

\section{Discussion}

Plants can contribute to the advancement of novel chemo-preventive agents as they have been proven essential in forming potentially useful structures. The initial step to this achievement is performing antibacterial activities [34]. Plants are the gifts of nature for producing a wide collection of phytochemicals that are related to stress or defense mechanisms as well as antimicrobial activities and play significant role [35]. This diverse existence of rich phytochemicals has become popular due to its enhanced defense mechanisms alongside a variety of microorganisms, nematodes, insects and other plants [36]. The existing literature suggests that phytochemicals documented for their antimicrobial potential belong to the major subclasses phenols, flavones, quinones, flavonols, terpenoids, coumarins, tannins, essential oils, polyamines, glycosides, alkaloids and many more [37, 38]. Although many classes of phytochemicals have been reported having antimicrobial abilities yet they have not been recognizes as therapeutic agents by the medical communal [39]. Secondly, to successfully predict which botanical compounds can be present in the plant material, it is important to keep in view the type of solvent used for extraction procedure. Traditional practitioners made the use of water as a solvent but studies reported proved that methanol extracts were undoubtedly much better and hence more powerful. This is recognized due to the better solubility of the plant active metabolites in organic solvents [40]. These clarifications can be rationalized by the escalating polarity of the compounds extracted by different solvents and their intrinsic bioactivity.

Our present study revealed good antibacterial and antifungal effect of plant extracts towards a panel of microorganisms under study. This may be due to the rich diversity of phytochemicals such as flavonoids, saponins, alkaloids, phenols and tannins present in the plant extracts in higher amounts as well as the type of solvent used to completely extract these bioactive compounds present within the plant. Results of quantitative analysis indicate highest phenol content in PJM, which comply to the statement that methanol, is undoubtedly considered the best solvent for extraction of phenolic compounds due to better solubility and polarity of the solvent [41]. Similar to the study conducted by [41], in which the methanol extract of thymus vulgaris showed maximum phenolic compounds per mg of GAE/g extract, our study also displayed similar results in case of PJM extract in comparison to PJC extract. A wide range of phenolic compounds are well-known for their antimicrobial potential, which may describe the potent antibacterial and antifungal activities of PJM in the present study. Apart from this, flavonoids are a chemical class most often correlated with antimicrobial efficacy of herbal extracts. Many flavonoids are well reported showing anti-infective effects by forming complexes with different extracellular proteins and proteins residing in bacterial cell wall [42]. Our study showed PJM to contain the highest flavonoid contents in addition to highest phenolic contents, which is in accordance with the findings of [42] who reported the methanol extract to have maximum phenolic and flavonoid levels, and displaying more pronounced antibacterial potential compared to

Table 8 Antifungal screening of $P$. jacquemontiana extracts and clotrimazole

\begin{tabular}{|c|c|c|c|c|c|c|c|c|c|c|c|c|}
\hline \multirow[b]{3}{*}{ Clinical Isolate(s) } & \multicolumn{9}{|c|}{ Extract/Fractions ( $\mu \mathrm{g} / \mathrm{ml})$} & \multirow{2}{*}{\multicolumn{3}{|c|}{$\frac{\text { Standard }(\mu \mathrm{g} / \mathrm{ml})}{\text { Clotrimazole }}$}} \\
\hline & \multicolumn{3}{|l|}{ PJM } & \multicolumn{3}{|l|}{ PJE } & \multicolumn{3}{|l|}{ PJB } & & & \\
\hline & MIC & MFC & $\overline{M F C / M I C}$ & $\overline{\mathrm{MIC}}$ & MFC & $\overline{M F C / M I C}$ & $\overline{M I C}$ & MFC & $\overline{M F C / M I C}$ & $\overline{M I C}$ & MFC & $\mathrm{MFC} / \mathrm{MIC}$ \\
\hline F. solani ATCC 36031 & 32 & 128 & 04 & 32 & 64 & 02 & 32 & 128 & 04 & 04 & 08 & 02 \\
\hline A. niger ATCC 6275 & 16 & 32 & 02 & 16 & 128 & 08 & 128 & 256 & 02 & 32 & 64 & 02 \\
\hline A. flavus ATCC 204304 & 08 & 32 & 04 & 32 & 256 & 08 & 128 & 512 & 04 & 32 & 128 & 04 \\
\hline M. piriformis ATCC 52554 & 32 & 128 & 04 & 08 & 128 & 16 & 32 & 64 & 02 & 08 & 16 & 02 \\
\hline C. albicans (90028) & 64 & 256 & 04 & 64 & 256 & 04 & 64 & 128 & 02 & 16 & 64 & 04 \\
\hline D. hansenii & 64 & 256 & 04 & 64 & 512 & 08 & 32 & 512 & 16 & 64 & 128 & 02 \\
\hline W. anomalus (KU949596) & 08 & 64 & 08 & 32 & 64 & 02 & 32 & 256 & 08 & 08 & 32 & 04 \\
\hline W. anomalus (KU949595) & 16 & 32 & 02 & 08 & 32 & 04 & 64 & 512 & 08 & 16 & 64 & 04 \\
\hline
\end{tabular}

MIC minimum inhibitory concentration, MFC minimum fungicidal concentration, PJM methanol extract of $P$. jacquemontiana leaves, PJE ethyl acetate fraction of PJM, PJB n-butanol fraction of PJM, PJA residual aqueous fraction of PJM 
other solvent extracted samples. Antibacterial activity was found to be more pronounced against gram positive bacteria compared to gram negative. This confides itself to the previous reports showing that plant extracts have better potential against gram positive microorganisms than gram negative [43, 44]. Gram positive and negative bacteria have different cell envelope structures. The outer membrane surrounding cell wall is found in negative bacteria only which will act as an impermeable membrane for the passage of substances through it whereas no outer membrane lining cell wall is present in gram positive bacterium. This allows the substances to easily access it as it is permeable to most substances. Generally, the plant extracts capable of inhibiting gram negative bacteria equally like the gram positive bacteria can be accredited to its total phenolic content, which when higher can act as broad-spectrum antibacterial agent whereas when lower then shows almost no antibacterial activity [45]. On a similar notice, one of the known resistant gram negative bacterial strain called Pseudomonas aeruginosa (27853), showed maximum sensitivity towards PJM compared to other extracts tested, which may be possible due to high phenol content present in PJM. Moreover it can be said that foods rich in polyphenols may significantly reduce the risk of various health problems due to their anti-mutagenic, ant-inflammatory, antioxidant, and antibacterial properties [46]. Another diverse studied plant phytochemical is saponins, which have also been claimed to possess antibacterial activity. Our study revealed saponin content to be present in PJM, PJE and PJB fractions only. All these plant extract samples showed promising antibacterial activity compared to other extracts (PJH, PJC and PJA) in which their presence was not detected. It can be said that high content of saponins and tannins present in plant extracts could be considered as the basis for its antimicrobial property as claimed previously that saponin and tannin rich plants have profound antimicrobial activity [47]. Tannins are one of the important chemical groups of compounds having constitutive structural function present in almost every plant part including leaves, fruits, roots, bark and wood [48]. They account for the astringent taste of unripe fruits or wine and are constituents of the different colors seen in flowers and autumn weather leaves [49]. Tannins have been reported to disrupt the cytoplasmic membrane, interrupt the PMF (proton motive force), active transport, coagulation of cell substances and electron flow [50]. This can be a reason that almost all the plant extract fractions of $P$. jacquemontiana having high tannin content were able to inhibit all the tested organisms especially the gram positive microorganisms, having lipopolysaccharide-deficient outer membrane and hence proved to be more susceptible towards them. Tannins can exist in two forms, either as condensed tannins or as hydrolysable tannins. Higher levels of tannins especially condensed tannins and polyphenols when present in plant extracts might be responsible for antibacterial mode of action and anticandidal activity [51]. One of the mechanisms of tannins accounting for antimicrobial potential involves extracellular enzyme inhibition. Condensed tannins have the ability to bind to cell coat polymers in strains, and form complexes resulting in inhibition of cell associated proteolytic activity of these strains. Morphology is also altered in the presence of condensed tannins implicating the role of tannin toxicity in targeting the cell wall. Moreover despite forming outer complexes with cell-coat polymers of bacterial strains, condensed tannins have the ability to penetrate through the cell wall in sufficient concentrations to react with other ultrastructural components resulting in inhibition of cell wall synthesis [52]. Condensed tannins were strongly present in PJM, PJE and PJB extracts marking their role as effective antimicrobial agents, showing broad-spectrum antimicrobial activity compared to PJH, PJC and PJA. Our results partially agree with [53], who claimed methanol extract to contain more condensed tannins compared to other extracts while our present study conducted revealed the manifestation of condensed tannins in PJM with equal intensity as in PJE and PJB, respectively. Another phytochemical class known as phlobatannins along with other chemical classes has been widely reported in the implication of causing inhibitory action against a wide range of micro-organisms when present in plants [54]. Phlobatannins were detected in PJM, PJE and PJB fractions which may account for outstanding antimicrobial activity compared to other extracts of P.jacquemontiana. Apart from this, another largest group of chemical compounds formed by the plants are alkaloids and they have proved their usefulness to humans as powerful pain killers hence relieving body pain [55]. Alkaloids are commonly known for their antimicrobial properties [56]. The present study indicated their presence in all plant extracts (except aqueous) paving the way for more effective research. Coumarins were also abundantly present in almost all fractions which are responsible for the stimulation of macrophages, hence playing an indirect negative role on infections [57]. It is known to inhibit $C$. albicans in vitro and is presumed to have antifungal potential also [58]. However terpenoids were absent in all fractions of this plant which are known for their effectiveness against bacteria, fungi and viruses [59-61]. Moreover the antibacterial potential of a crude extract has been demarcated as significant when its MIC value is less than $100 \mu \mathrm{g} / \mathrm{ml}$, moderate when $\mathrm{MIC}<625 \mu \mathrm{g} / \mathrm{ml}$ and low when MIC $>625 \mu \mathrm{g} / \mathrm{ml}[62,63]$.

Fungi spoil the food materials and worsen their nutritive value. Several studies have been carried out which 
attribute the phenolic composition to combat bacterial pathogens $[64,65]$, whereas saponin detection to combat fungal pathogens $[66,67]$. This can explain our plant fraction analysis in which PJM, PJE, and PJB having saponin content are showing promising antifungal results compared to the other fractions (PJH, PJC and PJA) in which saponin functional chemical group was not detected and hence it did not show activity against any fungal strain. A classification based on fungal MIC values of plant extracts was published which accredited an MIC value up to $500 \mu \mathrm{g} / \mathrm{ml}$ as a strong potential inhibitor, $600-1500 \mu \mathrm{g} / \mathrm{ml}$ was considered as moderate potential inhibitor and a value exceeding $1600 \mu \mathrm{g} / \mathrm{ml}$ was considered as weak potential inhibitor [68]. Triplicate results of antifungal activity showed that three fractions of P. jacquemontiana including PJM, PJE and PJB showed good antifungal potential displaying MIC values $\leq 500 \mu \mathrm{g} / \mathrm{ml}$, proving them as strong potential inhibitors of fungi. It is also to be mentioned that PJA (aqueous plant extract) did not show noteworthy antibacterial and antifungal activities compared to the other extracts. This is in compliance with the findings of [69], who concluded that methanol extract of Juniperus oxycedrus showed strong antibacterial and antifungal activity while aqueous extract of the same plant did not exhibit any sort of antibacterial, antifungal, or anti-candidal effects. This might be due to the nature of extraction solvent used as described previously that methanol is a more powerful solvent for extraction of bioactive constituents especially antimicrobial constituents from medicinal plants as compared to other solvents including water.

\section{Conclusion}

The results obtained in the present study conclude that all the methanol derived fractions of $P$. jacquemontiana leaf extract (except aqueous fraction) have strong antibacterial potential, especially against all MDR strains tested and three fractions (PJM, PJE and PJB) have strong antifungal potential with minimal MIC values. This can attribute to the phytochemical composition of the extracts. They can be a source of novel metabolites. The extracts also proved their anticandidal activity in these assays and can be utilized further for the discovery of novel anti-candidal agents. Moreover the plant extracts showing outstanding antimicrobial activities can be helpful in exposing novel antibiotic classes that can function as selective agents for health maintenance around the globe.

\section{Abbreviations}

MBC: Minimum bactericidal concentration; MDR: Multi-drug resistant; MFC: Minimum fungicidal concentration; MIC: Minimum inhibitory concentration; PJA: Parrotiopsis jacquemontiana soluble residual aqueous fraction of PJM; PJB: Parrotiopsis jacquemontiana butanol fraction of PJM; PJC: Parrotiopsis jacquemontiana chloroform fraction of ANM; PJE: Parrotiopsis jacquemontiana ethyl acetate fraction of PJM; PJH: Parrotiopsis jacquemontiana hexane fraction of PJM; PJM: Parrotiopsis jacquemontiana methanol extract of leaves

\section{Acknowledgements}

MRK is intensely acknowledged for his kind supervision, expert guidance and substantial facilitations of all necessary materials and equipment.

\section{Funding}

The project was funded by the Department of Biochemistry, Quaid-i-Azam University Islamabad, Pakistan.

\section{Availability of data and materials}

All the data is contained in the manuscript.

\section{Authors' contributions}

SA made significant contribution to experimentation, acquisition and drafting of the manuscript. MRK has made substantial contribution to designing, analyzing and drafting of the manuscript. IU, MS and ZZ made a contribution in the experimentation and acquisition of the data. All authors have read and approved the final manuscript.

\section{Authors' information}

MRK did his Diploma in Unani Medicine and Surgery (DUMS) and is a registered practitioner of the National Council for Tibb of Pakistan. He is working as Associate Professor at the Department of Biochemistry, Quaid-iAzam University, Islamabad, Pakistan.

Ethics approval and consent to participate Not applicable.

Consent for publication

Not applicable.

\section{Competing interests}

The authors declare that they have no competing interests.

\section{Publisher's Note}

Springer Nature remains neutral with regard to jurisdictional claims in published maps and institutional affiliations.

Received: 8 February 2017 Accepted: 26 January 2018

Published online: 31 January 2018

\section{References}

1. Walsh TR, Toleman MA, Poirel L, Nordmann P. Metallo- $\beta$-lactamase: the quiet before the storm. Clin Microbiol Rev. 2005:18:306-25.

2. Loper J, Henkels M, Roberts R, Grove G, Willet M, Smith T. Evaluation of streptomycin, oxytetracycline, and copper resistance of Erwinia amylovora isolated from pear orchards in Washington state. Plant Dis. 1991;75:287-90.

3. Davies J. Inactivation of antibiotics and the dissemination of resistance genes. Science. 1994:264:375-82.

4. Service RF. Antibiotics that resist resistance. Science (New York, NY). 1995; 270:724.

5. Khan AU, Musharraf A. Plasmid-mediated multiple antibiotic resistance in Proteus Mirabilis isolated from patients with urinary tract infection. Med Sci Monit. 2004;10:CR598-602.

6. De Lencastre H, Oliveira D, Tomasz A. Antibiotic resistant Staphylococcus Aureus: a paradigm of adaptive power. Curr Opin Microbiol. 2007;10:428-35.

7. Sato $Y$, Oketani $H$, Singyouchi $K$, OHTSUBO T, KIHARA M, SHIBATA H, HIGUTI T. Extraction and purification of effective antimicrobial constituents of Terminalia chebula Rets. Against methicillin-resistant Staphylococcus aureus. Biol Pharm Bull. 1997:20:401-4.

8. Tsuchiya H, Sato M, Miyazaki T, Fujiwara S, Tanigaki S, Ohyama M, Tanaka T, linuma M. Comparative study on the antibacterial activity of phytochemical flavanones against methicillin-resistant Staphylococcus aureus. J Ethnopharmacol. 1996:50:27-34.

9. Paula CR, Krebs VL, Auler ME, Ruiz LS, Matsumoto FE, Silva EH, Diniz EM, Vaz FA. Nosocomial infection in newborns by Pichia anomala in a Brazilian intensive care unit. Med Mycol. 2006;44:479-84. 
10. Clark AM. Natural products as a resource for new drugs. Pharm Res. 1996;13: 1133-41.

11. Cordell GA. Biodiversity and drug discovery — a symbiotic relationship. Phytochemistry. 2000;55:463-80.

12. Balouiri M, Sadiki M, Ibnsouda SK. Methods for in vitro evaluating antimicrobial activity: a review. Chin J Pharm Anal. 2016;6:71-9.

13. Hazrat A. Taxo ethnobotanical survey and biological activities of selected medicinal plants of dir Kohistan Khyber Pakhtunkhwa Pakistan. Khyber Pakhtunkhwa: University Of Malakand; 2013.

14. Malik A, Siddique M, Sofi P, Butola J. Ethnomedicinal practices and conservation status of medicinal plants of north Kashmir Himalayas. Res J Med Plant. 2011;5:515-30.

15. Mir MY, Wani M, Bhat JA, Malla R, Moheen HA. Manuscript Info Abstract. Int J. 2013;1:43-7.

16. Mir MY. Indigenous knowledge of using medicinal plants in treating skin diseases by tribal's of Kupwara, J\&K, India. Int J Herbal Med. 2014;1:62-8.

17. Archana P, Samatha T, Mahitha B, Chamundeswari NR. Preliminary phytochemical screening from leaf and seed extracts of Senna alata $\mathrm{L}$. Roxb- an ethno medicinal plant. Int J Pharm Biol Res. 2012;3:82-9.

18. Evans WC. Trease and Evans. Pharmacognosy. 1989;33:471.

19. Harborne A. Phytochemical methods a guide to modern techniques of plant analysis: Springer science \& business media). 1998.

20. Evans W. Trease and Evans' Pharmacognosy 15th edition Elsevier Health Sciences New York. Chapter 6 References. 2002. p. 21-24.

21. Sofowara E. Phytochemical Screening of Medicinal Plants and Traditional Medicine in Africa. Ibadan: Spectrum Books Ltd.; 1993

22. Harborne JB. Phenolic compoiunds a guide to modern techniques of plant analysis. London: Academic Press; 1973.

23. Krishnaiah D, Devi T, Bono A, Sarbatly R. Studies on phytochemical constituents of six Malaysian medicinal plants. J Med Plant Res. 2009;3: 067-72.

24. Buren J, Robinson W. Formation of complexes between protein and tannic acid. J Agric Food Chem. 1969;17:772-7.

25. Singh R, Verma PK, Singh G. Total phenolic, flavonoids and tannin contents in different extracts of Artemisia absinthium. J Intercult Ethnopharmacol. 2012;1:101-4.

26. Obadoni B, Ochuko P. Phytochemical studies and comparative efficacy of the crude extracts of some haemostatic plants in Edo and Delta states of Nigeria. Global J Pure Appl Sci. 2002;8:203-8.

27. Sharma A, Chandraker S, Patel VK, Ramteke P. Antibacterial activity of medicinal plants against pathogens causing complicated urinary tract infections. Indian J Pharm Sci. 2009;71:136-9.

28. Mahesh B, Satish S. Antimicrobial activity of some important medicinal plant against plant and human pathogens. World J Agric Sci. 2008;4:839-43.

29. Ambrosio CM, de Alencar SM, de Sousa RL, Moreno AM, Da Gloria EM. Antimicrobial activity of several essential oils on pathogenic and beneficial bacteria. Ind Crop Prod. 2017;97:128-36.

30. Eloff J. A sensitive and quick microplate method to determine the minimal inhibitory concentration of plant extracts for bacteria. Planta Med. 1998;64:711-3.

31. Şahin F, Karaman I, Güllüce $M$, Öğütçü H, Şengül M, Adıgüzel A, Öztürk S, Kotan R. Evaluation of antimicrobial activities of Satureja hortensis L. J Ethnopharmacol. 2003;87:61-5.

32. Suffredini I, Sader HS, Gonçalves AG, Reis AO, Gales AC, Varella AD, Younes RN. Screening of antibacterial extracts from plants native to the Brazilian Amazon rain Forest and Atlantic Forest. Braz J Med Biol Res. 2004;37:379-84.

33. Akremi N, Cappoen D, Anthonissen R, Verschaeve L, Bouraoui A. Phytochemical and in vitro antimicrobial and genotoxic activity in the brown algae Dictyopteris Membranacea. S Afr J Bot. 2017;108:308-14.

34. Tona L, Cimanga R, Mesia K, Musuamba C, De Bruyne T, Apers S, Hernans N, Van Miert S, Pieters L, Totté J. In vitro antiplasmodial activity of extracts and fractions from seven medicinal plants used in the Democratic Republic of Congo. J Ethnopharmacol. 2004;93:27-32.

35. Dixon RA. Natural products and plant disease resistance. Nature. 2001;411:843-7.

36. Dangl JL, Jones JD. Plant pathogens and integrated defence responses to infection. Nature. 2001;411:826-33.

37. Gibbons S, Moser E, Kaatz GW. Catechin gallates inhibit multidrug resistance (MDR) in Staphylococcus Aureus. Planta Med. 2004;70:1240-2.

38. Stavri M, Piddock $\sqcup$, Gibbons S. Bacterial efflux pump inhibitors from natural sources. J Antimicrob Chemother. 2007;59:1247-60.

39. Gibbons S. Anti-staphylococcal plant natural products. Nat Prod Rep. 2004; 21:263-77.
40. de Boer HJ, Kool A, Broberg A, Mziray WR, Hedberg I, Levenfors JJ. Anti-fungal and anti-bacterial activity of some herbal remedies from Tanzania. J Ethnopharmacol. 2005;96:461-9.

41. Roby MHH, Sarhan MA, Selim KA-H, Khalel KI. Evaluation of antioxidant activity, total phenols and phenolic compounds in thyme (Thymus Vulgaris L.), sage (Salvia Officinalis L.), and marjoram (Origanum Majorana L.) extracts. Ind Crop Prod. 2013;43:827-31.

42. Mahboubi A, Asgarpanah J, Sadaghiyani PN, Faizi M. Total phenolic and flavonoid content and antibacterial activity of Punica Granatum L. Var. Pleniflora flowers (Golnar) against bacterial strains causing foodborne diseases. BMC Complement Altern Med. 2015;15:366.

43. Rabe T, Van Staden J. Antibacterial activity of south African plants used for medicinal purposes. J Ethnopharmacol. 1997:56:81-7.

44. Vlietinck A, Van Hoof L, Totte J, Lasure A, Berghe DV, Rwangabo P, Mvukiyumwami J. Screening of hundred Rwandese medicinal plants for antimicrobial and antiviral properties. J Ethnopharmacol. 1995;46:31-47.

45. Butkhup L, Chowtivannakul S, Gaensakoo R, Prathepha P, Samappito S. Study of the phenolic composition of shiraz red grape cultivar (Vitis Vinifera L.) cultivated in north-eastern Thailand and its antioxidant and antimicrobial activity. S Afr J Enol Vitic. 2016;31:89-98.

46. Alves MJ, Ferreira IC, Froufe HJ, Abreu R, Martins A, Pintado M. Antimicrobial activity of phenolic compounds identified in wild mushrooms, SAR analysis and docking studies. J Appl Microbiol. 2013;115:346-57.

47. Ohadoma S, Nnatuanya I, Amazu L, Okolo C. Antimicrobial activity of the leaf extract and fractions of Lupinus Arboreus. J Med Plant Res. 2014;8:386-91.

48. Scalbert A. Antimicrobial properties of tannins. Phytochemistry. 1991;30:3875-83.

49. Bergey DR, Howe GA, Ryan CA. Polypeptide signaling for plant defensive genes exhibits analogies to defense signaling in animals. Proc Natl Acad Sci. 1996:93:12053-8.

50. Burt S. Essential oils: their antibacterial properties and potential applications in foods-a review. Int J Food Microbiol. 2004;94:223-53.

51. Sampaio T, Cartaxo-Furtado N, de Medeiros A, Alves H, Rosalen P, Pereira J. Antimicrobial potential of plant extracts and chemical fractions of Sideroxylon Obtusifolium (Roem. \& Schult.) TD Penn on oral microorganisms. J Contemp Dent Pract. 2017;18:392-8.

52. Min B, Barry T, Attwood G, McNabb W. The effect of condensed tannins on the nutrition and health of ruminants fed fresh temperate forages: a review. Anim Feed Sci Technol. 2003;106:3-19.

53. Medini F, Fellah H, Ksouri R, Abdelly C. Total phenolic, flavonoid and tannin contents and antioxidant and antimicrobial activities of organic extracts of shoots of the plant Limonium Delicatulum. J Taibah Univ Sci. 2014;8:216-24.

54. Arekemase M, Kayode R, Ajiboye A. Antimicrobial activity and phytochemical analysis of Jatropha Curcas plant against some selected microorganisms. Int J Biol. 2011:3:52.

55. Raffauf RF. Plant alkaloids: a guide to their discovery and distribution: food products press. 1996.

56. Omulokoli E, Khan B, Chhabra S. Antiplasmodial activity of four Kenyan medicinal plants. J Ethnopharmacol. 1997;56:133-7.

57. Casley-Smith J, Casley-Smith J. Coumarin in the treatment of lymphoedema and other high-protein oedemas. Coumarins: biology, applications and mode of action. New York: Wiley; 1997. p. 348.

58. Hoult J, Paya M. Pharmacological and biochemical actions of simple coumarins: natural products with therapeutic potential. Gen Pharmacol. 1996;27:713-22.

59. Amaral J, Ekins A, Richards S, Knowles R. Effect of selected monoterpenes on methane oxidation, denitrification, and aerobic metabolism by bacteria in pure culture. Appl Environ Microbiol. 1998;64:520-5.

60. Fujioka T, Kashiwada Y, Kilkuskie RE, Cosentino LM, Ballas LM, Jiang JB, Janzen WP, Chen I-S, Lee K-H. Anti-AIDS agents, 11. Betulinic acid and platanic acid as anti-HIV principles from Syzigium claviflorum, and the antiHIV activity of structurally related triterpenoids. J Nat Prod. 1994;57:243-7.

61. Suresh B, Sriram S, Dhanaraj S, Elango K, Chinnaswamy K. Anticandidal activity of Santolina chamaecyparissus volatile oil. J Ethnopharmacol. 1997; 55:151-9.

62. Efferth T, Kuete V. Cameroonian medicinal plants: pharmacology and derived natural products. Front Pharmacol. 2010;1:123.

63. Kuete V. Potential of Cameroonian plants and derived products against microbial infections: a review. Planta Med. 2010;76:1479-91.

64. Baydar NG, Sagdic O, Ozkan G, Cetin S. Determination of antibacterial effects and total phenolic contents of grape (Vitis Vinifera L.) seed extracts. Int J Food Sci Technol. 2006;41:799-804. 
65. Rodríguez N, Amils R, Jiménez-Ballesta R, Rufo L, de la Fuente V. Heavy metal content in Erica andevalensis: an endemic plant from the extreme acidic environment of Tinto River and its soils. Arid Land Res Manag. 2007; 21:51-65.

66. Aboaba O, Efuwape B. Antibacterial properties of some Nigerian species. Bio Res Comm. 2001;13:183-8.

67. Mohanta T, Patra J, Rath S, Pal D, Thatoi H. Evaluation of antimicrobial activity and phytochemical screening of oils and nuts of Semicarpus anacardium If. Sci Res Essays. 2007;2:486-90.

68. Aligiannis N, Kalpoutzakis E, Mitaku S, Chinou IB. Composition and antimicrobial activity of the essential oils of two Origanum species. J Agric Food Chem. 2001;49:4168-70.

69. Karaman I, Şahin F, Güllüce M, Öğütçü H, Şengül M, Adıgüzel A. Antimicrobial activity of aqueous and methanol extracts of Juniperus Oxycedrus L. J Ethnopharmacol. 2003;85:231-5.

Submit your next manuscript to BioMed Central and we will help you at every step:

- We accept pre-submission inquiries

- Our selector tool helps you to find the most relevant journal

- We provide round the clock customer support

- Convenient online submission

- Thorough peer review

- Inclusion in PubMed and all major indexing services

- Maximum visibility for your research

Submit your manuscript at www.biomedcentral.com/submit
Biomed Central 